\title{
IL-10 Inhibits Metalloproteinase and Stimulates TIMP-1 Production in Human Mononuclear Phagocytes
}

Sylvie Lacraz, Laurent P. Nicod, ${ }^{*}$ Rachel Chicheportiche, Howard G. Welgus, ${ }^{\star}$ and Jean-Michel Dayer

Division of Immunology and Allergy (Hans Wilsdorf Laboratory), *Division of Respiratory Diseases, Department of Medicine, University Hospital, Geneva, Switzerland; and ${ }^{\ddagger}$ Division of Dermatology, Department of Medicine, Washington University School of

Medicine at Jewish Hospital, St. Louis, Missouri 63110

\begin{abstract}
Human mononuclear phagocytes can modulate the turnover of extracellular matrix by producing metalloproteinases such as 92-kD gelatinase and interstitial collagenase as well as the tissue inhibitor of metalloproteinases (TIMP). We have previously reported that IL-4 and IFN $\gamma$ released by lymphocytes suppress metalloproteinase biosynthesis in macrophages without affecting TIMP production (Lacraz, S., L. Nicod, B. C. de Rochementeix, C. Baumberger, J. Dayer, and H. Welgus. 1992. J. Clin. Invest. 90:382-388.; Shapiro, S. D., E. J. Campbell, D. K. Kobayashi, and H. G. Welgus 1990. J. Clin. Invest. 86:1204-1210). Like IL-4, IL10 is secreted by $\mathrm{Th}_{\mathbf{2}}$ lymphocytes and is inhibitory to several macrophage functions. In the present study, IL-10 was tested and compared to IL-2, IL-4, IL-6, and IFN $\gamma$ for its capacity to modulate synthesis of $92-\mathrm{kD}$ gelatinase, interstitial collagenase and TIMP in human macrophages and monocytes. We found that IL-10, just like IL-4, inhibited the production of 92-kD gelatinase and blocked LPS-, as well as killed Staphylococcus aureus-induced, interstitial collagenase production. The principal finding of this study, however, was that IL-10, in distinction to $\mathrm{IL}-4$, produced a dose-dependent stimulation in the biosynthesis of TIMP-1. TIMP-2 production was not affected. IL-10 regulated the expression of 92-kD gelatinase and TIMP-1 at the pretranslational level. Furthermore, IL-10 regulation was cell typespecific, as it had no effect on the production of metalloproteinases or TIMP by human fibroblasts. In summary, IL10 has a potent and unique effect upon tissue macrophages and blood monocytes by enhancing TIMP-1 production while decreasing metalloproteinase biosynthesis. (J. Clin. Invest. 1995. 96:2304-2310.) Key words: IL-10 • TIMP • metalloproteinase $\bullet$ mononuclear phagocytes $\bullet$ lymphokines
\end{abstract}

\section{Introduction}

Macrophages play an important role in the immune response, in acute and chronic inflammation, and they participate in degra-

Address correspondence to Jean-Michel Dayer, M.D., Division of Immunology and Allergy, University Hospital, 24, rue Micheli-du-Crest, 1211 Geneva 14, Switzerland. FAX: 22-3729418.

Received for publication 24 May 1995 and accepted in revised form 3 August 1995.

J. Clin. Invest.

(C) The American Society for Clinical Investigation, Inc.

0021-9738/95/11/2304/07 \$2.00

Volume 96, November 1995, 2304-2310 dation and remodelling of extracellular matrix (ECM). ${ }^{1}$ These cells are able to modulate matrix turnover by synthesizing and secreting several metalloproteinases and their specific inhibitors, tissue inhibitors of metalloproteinases (TIMPs) $(1,2)$. Such enzymes include interstitial collagenase, stromelysin, gelatinases of 92 and $72 \mathrm{kD}(2,3)$ of which the former is predominant (4), and a newly described metalloelastase (5). Macrophages also produce the counter-regulatory inhibitors TIMP-1 and TIMP-2 $(6,7)$. TIMP-1 interacts with the active forms of interstitial collagenase and stromelysin as well as with the active and latent form of $92-\mathrm{kD}$ gelatinase. TIMP-2 specifically binds the proenzyme and active species of $72-\mathrm{kD}$ gelatinase. Both TIMPs inhibit the activity of the fully competent metalloproteinases and also diminish metalloproteinase precursor activation (8).

The prominence of mononuclear phagocytes in inflammatory sites is the result of their attraction by mediators such as leukotrienes, chemokines and complement split products. These cells, in addition to fibroblast-like cells, may contribute significantly to the degradation and pathological remodelling of ECM Support for this concept is found by in situ hybridization studies demonstrating high levels of interstitial collagenase and stromelysin mRNA in macrophage-like cells of the rheumatoid synovial pannus (9) and also in lipid-laden macrophages of atherosclerotic plaques (10). In addition, during inflammatory processes, other migratory cells are often present, including B- and $\mathrm{T}$ lymphocytes. $\mathrm{T}$ lymphocytes can interact with mononuclear cells through released peptides, such as lymphokines (11) or by direct cell-cell contact (12). The lymphokine profiles of $\mathrm{Th}_{1}$ and $\mathrm{Th}_{2} \mathrm{~T}$ helper cells are distinct and may be able to modify specific macrophage functions, in particular their ability to degrade ECM (13).

IL-10 is primarily a product of activated $\mathrm{Th}_{2}$ cells (14) and of LPS-stimulated monocytes (15), but it is also synthesized by B cells (16) and keratinocytes (17). Among the different cell types affected by IL-10, monocyte-macrophages appear to be particularly modified in regard to their function, morphology, and phenotype. For instance, IL-10 strongly diminishes the production of IL- $1 \alpha$, IL- $1 \beta$, IL-6, IL-8, TNF $\alpha$, GM-CSF, and GCSF by LPS-activated human monocytes (15). It also inhibits the antigen-specific proliferative $T$ cell response by reducing the antigen-presenting capacity of monocytes via downregulation of class II MHC molecules (18). Thus, IL-10 appears to be a potent suppressor of the immune response.

To determine the effect of IL-10 upon the capacity of macrophages to modulate ECM degradation, we compared the ability

1. Abbreviations used in this paper: ECM, extracellular matrix; Killed Staph., killed Staphylococcus aureus; MMP, matrix metalloproteinase; TIMP, tissue inhibitor of metalloproteinases. 
of this cytokine to regulate the production of matrix metalloproteinases and TIMPs to that of IL-4, another product of activated $\mathrm{Th}_{2} \mathrm{~T}$ helper cells which has been previously shown to inhibit the expression of interstitial collagenase and $92-\mathrm{kD}$ gelatinase by mononuclear phagocytes without affecting the synthesis of TIMP-1 $(19,20)$. We have found that like IL-4, IL-10 can suppress metalloproteinase production by human mononuclear phagocytes. In addition, however, IL-10 potently stimulates TIMP-1 biosynthesis at both protein and gene levels. Thus, IL10 may have powerful antiinflammatory effects by counteracting macrophage degradative functions and by altering the proteinase/antiproteinase balance of this cell in favor of matrix preservation.

\section{Methods}

Reagents. Recombinant human IL-10 and specific monoclonal antiserum to human IL-10 ( $\alpha \mathrm{IL}-10$ ) were kindly provided by DNAX Inc. (Palo Alto, CA). Recombinant human IL-4 and human IL-6 were obtained from Sandoz Ltd. (Basel, Switzerland). Recombinant human IFN $\gamma$ and IL-2 were obtained from Biogen S.A. (Geneva, Switzerland). Amounts of endotoxin were quantified in all cytokines and antibodies used in these studies by the limulus amebocyte lysate assay (QCL1000; Whittaker M. A. Bioproducts, Walkersville, MD). All reagents contained $<0.05 \mathrm{ng} / \mathrm{ml}$ of endotoxin. Killed Staphylococcus aureus (killed Staph.) (generously supplied by Dr. S. Kantengwa, Allergology Unit, University Hospital, Geneva) was prepared as previously described (20). Bovine serum albumin (BSA), lipopolysaccharide (LPS), phenylmethylsulfonyl fluoride (PMSF), EDTA, Triton X-100 and protein A-Sepharose were obtained from Sigma Chemical Co. (St. Louis, MO). RPMI-1640, modified Eagle's medium (MEM), phosphate-buffered saline (PBS), fetal calf serum (FCS), penicillin, streptomycin and L-glutamine were purchased from GIBCO BRL (Paisley, Scotland).

Cell culture. Human alveolar macrophages were harvested from the uninvolved lung tissue of individuals undergoing surgical resection for pulmonary carcinoma (21). Segments or lobes were lavaged and processed as described previously (20). The adherent macrophages were cultured at a concentration of $1 \times 10^{6}$ cells $/ \mathrm{ml}$ in the presence of RPMI1640 medium, containing $5 \%$ FCS, penicillin $(100 \mathrm{U} / \mathrm{ml})$, streptomycin $(100 \mathrm{ng} / \mathrm{ml})$ and $2 \mathrm{mM}$ L-glutamine in 24-well cluster plates (Costar Corp., Cambridge, MA). The cells were maintained in humidified $95 \%$ air/ $5 \% \mathrm{CO}_{2}$. Cultures were treated with medium alone, killed Staph, LPS and/or various concentrations of the different cytokines for $48 \mathrm{~h}$. The conditioned media were then collected and stored at $-20^{\circ} \mathrm{C}$ until further analysis.

Peripheral blood monocytes were obtained by phlebotomy of normal adult volunteers. The mononuclear fraction was purified by Ficoll-Hypaque gradient centrifugation (Pharmacia Fine Chemicals, Piscataway, $\mathrm{NJ})$. Monocytes were plated at a concentration of $1 \times 10^{6} \mathrm{cells} / \mathrm{ml}$ and isolated by adherence to plastic at $37^{\circ} \mathrm{C}$ for $1 \mathrm{~h}$. Nonadherent cells were washed away three times with PBS and the resulting adherent cells were cultured in the presence of RPMI-1640 medium, containing 5\% FCS, penicillin $(100 \mathrm{U} / \mathrm{ml})$, streptomycin $(100 \mathrm{ng} / \mathrm{ml})$ and $2 \mathrm{mM}$ L-glutamine in 24-well cluster plates. The cells were maintained in humidified $95 \%$ air $/ 5 \% \mathrm{CO}_{2}$ for $48 \mathrm{~h}$. Cells were then treated with culture medium alone or various concentrations of IL-4, IL-10, and/or $\alpha \mathrm{IL}-10$. After 48 $\mathrm{h}$ of incubation at $37^{\circ} \mathrm{C}$, the conditioned media were collected and stored at $-20^{\circ} \mathrm{C}$ until further analysis.

Dermal fibroblasts were obtained by proteolytic dispersion of human skin, and lung fibroblasts were obtained by proteolytic dispersion of the uninvolved lung tissue of individuals undergoing surgical resection (22). Fibroblasts were plated in 96-well cluster plates (Costar Corp.) at $2 \times 10^{4}$ cells per $200 \mathrm{ml}$ MEM containing 5\% heat-inactivated FCS After $36 \mathrm{~h}$ of culture, the fibroblast monolayers were fed with new fresh MEM, and various cytokines were added for $72 \mathrm{~h}$. Conditioned media were then collected and the content of interstitial collagenase and TIMP1 was determined by ELISA.

Enzyme determinations. Samples of conditioned media were subjected to enzyme-linked immunosorbent assays (ELISA). The assays for interstitial collagenase, $92-\mathrm{kD}$ gelatinase and TIMP-1 have been previously described $(23-25)$. The sensitivity for all protein assays is $10 \mathrm{ng} / \mathrm{ml}$.

Metabolic labeling and immunoprecipitation studies. All samples subjected to immunoprecipitation were conditioned in the presence of $\left[{ }^{35} \mathrm{~S}\right]$ methionine for $24 \mathrm{~h}$. To determine the effects of IL-10 on the production of metalloproteinases by macrophages, cells were exposed to this cytokine for a period of $24 \mathrm{~h}$ in RPMI-1640 culture medium containing 5\% FCS and then washed three times in PBS. For the labeling period of $24 \mathrm{~h}$, RPMI- 1640 culture medium was replaced with otherwise identical methionine-free RPMI-1640 medium (GIBCO) containing 50 $\mu \mathrm{Ci} / \mathrm{ml}$ of $\left[{ }^{35} \mathrm{~S}\right]$ methionine (Amersham Corp., Zurich, Switzerland) and dialyzed 5\% FCS. After $24 \mathrm{~h}$ of incubation, the samples containing the labeled proteins were collected and stored at $-70^{\circ} \mathrm{C}$ until further analysis. For immunoprecipitation, polyclonal antisera to human interstitial collagenase, TIMP-1 and TIMP-2 were used as reported previously (3, 8,26 ). Processed samples were applied to $12 \%$ polyacrylamide slab gels and electrophoresis was performed as described (27). The gels were exposed to Hyperfilm film (Amersham, CEA AB, Solna, Sweden) for $24-48 \mathrm{~h}$ at $-70^{\circ} \mathrm{C}$.

RNA preparation and Northern hybridization. Total cellular RNA from $1 \times 10^{7}$ alveolar macrophages, untreated or exposed to IL-6 or various concentrations of IL-10, was extracted by the guanidine isothiocyanate method and purified by cesium chloride density gradient centrifugation (28). Total RNA (10 $\mu \mathrm{g})$ was processed for Northern analysis as described previously (23). Membranes were sequentially hybridized at $58^{\circ} \mathrm{C}$ overnight with ${ }^{32} \mathrm{P}$-labeled cDNA probes for $92-\mathrm{kD}$ gelatinase (4) and TIMP-1 (kindly provided by David Carmichael, Synergen, Boulder, CO). The 92-kD cDNA plasmid was digested with BamHI and $\mathrm{XbaI}$ in order to obtain a probe of $0.56 \mathrm{~Kb}$ as described previously (29). $18 \mathrm{~S}$ and $28 \mathrm{~S}$ rRNA bands stained with ethidium bromide were used as a control. Filters were then exposed to Hyperfilm film (Amersham, CEA AB, Solna, Sweden) for $24-48 \mathrm{~h}$ at $-70^{\circ} \mathrm{C}$.

\section{Results}

IL-10 suppresses MMP and stimulates TIMP-1 production by human mononuclear phagocytes. To determine whether IL-10 regulates the production of $92-\mathrm{kD}$ gelatinase and TIMP by human alveolar macrophages, the cells were exposed to increasing concentrations of this cytokine. For comparison, IL-4 was also tested. As shown in Fig. 1, macrophages under basal conditions released both $92-\mathrm{kD}$ gelatinase and TIMP-1 in culture. The addition of either IL-10 or IL- 4 resulted in a dose-dependent decrease of $92-\mathrm{kD}$ enzyme production. IL-4 at $10 \mathrm{ng} / \mathrm{ml}$ inhibited gelatinase production by $55 \%$ whereas an identical concentration of IL-10 caused a $37 \%$ decrease. Interestingly, IL-10 strongly stimulated the production of TIMP-1 in a dose-dependent manner, whereas IL-4, at various concentrations, failed to affect TIMP-1 synthesis. The time course of IL-10 regulation of $92-\mathrm{kD}$ gelatinase and TIMP-1 production was next examined. As shown in Fig. 2, IL-10 inhibited the production of $92-\mathrm{kD}$ gelatinase, but only 12-24 h after the addition of the cytokine, whereas stimulation of TIMP-1 synthesis occurred earlier, between $4-12 \mathrm{~h}$ of exposure.

To determine whether the activities of these cytokines extended to less differentiated forms of mononuclear phagocytes, we studied human peripheral blood monocytes exposed to IL10 and IL-4. Both cytokines suppressed the production of 92 $\mathrm{kD}$ gelatinase in monocytes in a dose-dependent manner (Fig. 


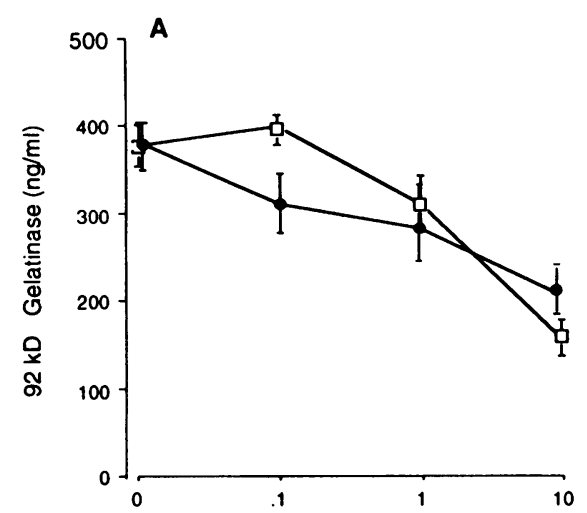

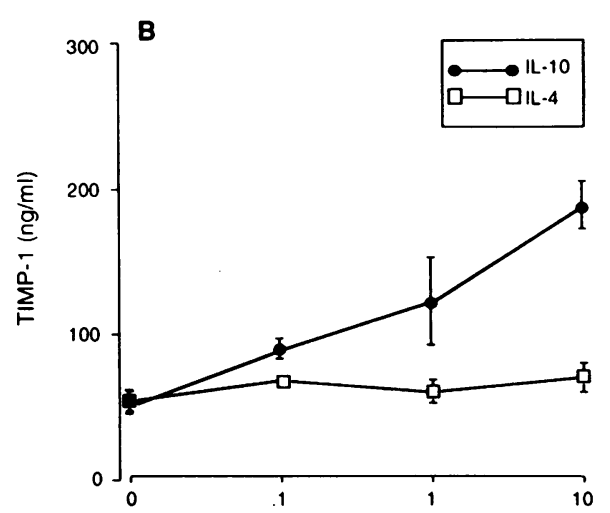

[ Cytokines, $\mathrm{ng} / \mathrm{ml}$ ]
Figure 1. Dose-dependent effect of IL-10 and IL-4 on the production of $92-\mathrm{kD}$ gelatinase and TIMP-1 by human alveolar macrophages. Macrophages were cultured for $48 \mathrm{~h}$ at $1 \times 10^{6}$ cells $/ \mathrm{ml}$ in the presence of increasing concentrations of IL-10 or IL-4. Conditioned media were collected and subjected to ELISA for determination of $92-\mathrm{kD}$ gelatinase $(A)$ and TIMP-1 $(B)$ content. Mean \pm SEM from three separate experiments.
3 A). However, only IL-10 significantly increased TIMP-1 production; IL-4 did not alter the release of metalloproteinase inhibitor (Fig. 3 B).

To verify the specificity of IL-10 effects, antiserum to this cytokine was used. As shown in Table I, IL-10 decreased the basal release of $92-\mathrm{kD}$ gelatinase in both alveolar macrophages and blood monocytes, an effect which was reversed by the simultaneous presence of cytokine antibody. Furthermore, IL10 markedly stimulated TIMP-1 production by both tissue macrophages and blood monocytes; this effect was also blocked by IL-10 antibody. In contrast a nonspecific antibody ( $\mathrm{mIgG}$ ) was totally unable to block the effects of IL-10 on both enzyme and inhibitor.

Effect of IL-10 on activated alveolar macrophages. To determine whether IL-10 would also modify the biological function of activated alveolar macrophages, cells were treated with either killed Staph. or LPS and were simultaneously exposed to the cytokine. As shown in Table II, the addition of killed Staph. markedly induced the expression of interstitial collagenase and $92-\mathrm{kD}$ gelatinase. IL-10 added simultaneously abrogated this response, reducing metalloproteinase production to baseline levels. Killed Staph. also induced the production of TIMP-1; this effect was enhanced nearly fourfold by IL-10. Thus, IL-10 exhibited identical activities upon both basal macrophages and cells stimulated by killed Staph.

Macrophage activation was also studied in response to LPS. Cells were cultured for $48 \mathrm{~h}$ in the presence or absence of LPS, with or without added IL-10, and were metabolically labeled with $\left[{ }^{35} \mathrm{~S}\right]$ methionine for the final $24 \mathrm{~h}$ of incubation. Labeled proteins were immunoprecipitated with antisera specific for interstitial collagenase, TIMP-1 and TIMP-2. Fig. 4 demonstrates that basal macrophages failed to synthesize collagenase, whose expression was massively induced by LPS. In the presence of IL-10, LPS-stimulated biosynthesis of interstitial collagenase was substantially reduced. Both basal and LPS-stimulated levels of TIMP-1 were markedly increased by exposure of the cells to IL-10. Labeled cellular proteins from the same experiment were also immunoprecipitated with antiserum specific for TIMP-2. As shown in Fig. 4 (last lane), macrophages spontaneously synthesized considerable amounts of TIMP-2, and consistent with our previous findings (9), production of TIMP-2 was decreased by LPS. However, the addition of IL-10 to such cultures failed to alter either basal or LPS-treated levels of TIMP-2. This type of experiment was not performed on peripheral blood monocytes because they are not responsive in their MMP production to LPS or killed Staph.

Pretranslational control of 92-kD gelatinase and TIMP-1 expression by $I L-10$. To study the mechanisms of IL-10 action on alveolar macrophages, steady-state mRNA levels of 92-kD gelatinase and TIMP-1 were examined by Northern blot hybridization. As shown in Fig. 5, IL-10 produced a dose-dependent increase in TIMP-1 mRNA as compared to untreated cells. Furthermore, IL-10 inhibited levels of $92-\mathrm{kD}$ gelatinase mRNA also in a dose-dependent manner. A stimulatory effect of IL-6

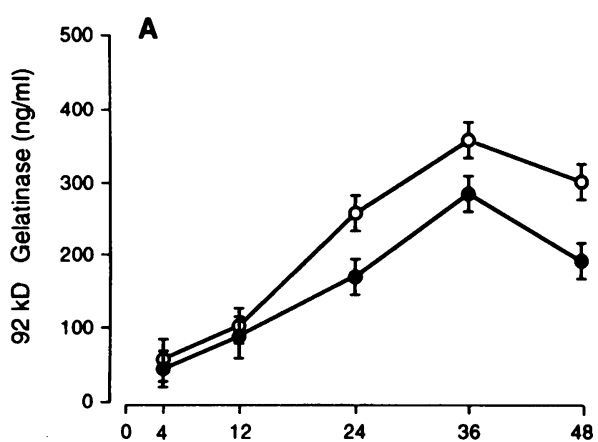

Time after cytokine addition (h)

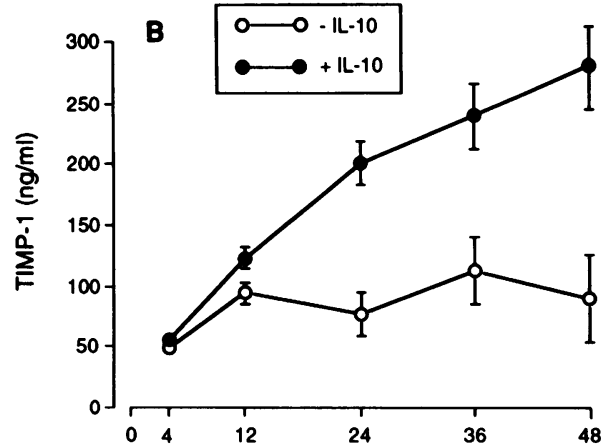

Figure 2. Time course of IL-10 regulation of $92-\mathrm{kDa}$ gelatinase and TIMP- 1 production by macrophages. Macrophages $\left(1 \times 10^{6}\right.$ cells $/ \mathrm{ml})$ were cultured in the absence or presence of IL-10 (10 ng/ $\mathrm{ml})$ for the times indicated and content of secreted $92-\mathrm{kD}$ gelatinase $(A)$ and TIMP-1 $(B)$ was determined. Values represent mean $\pm \operatorname{SEM}(n=3)$ of 1 experiment which is representative of two experiments with similar results. 


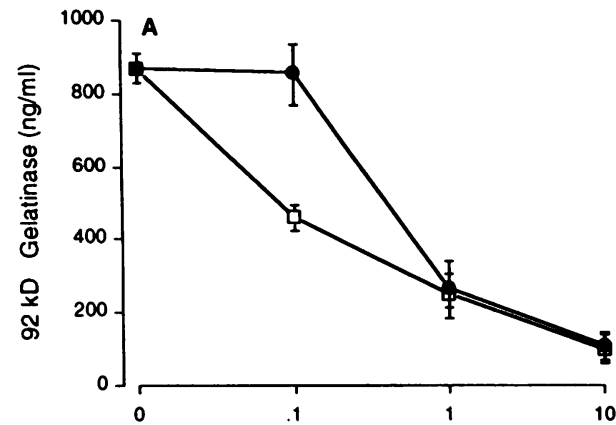

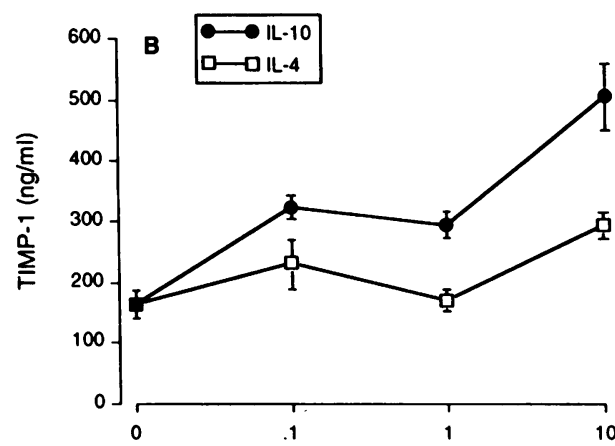

Figure 3. Concentration dependence of IL-10 and $\mathrm{IL}-4$ regulation of 92-kD gelatinase and TIMP-1 production by human peripheral blood monocytes. Monocytes were cultured at $1 \times 10^{6} \mathrm{cells} / \mathrm{ml}$ for $48 \mathrm{~h}$ in the presence of increasing concentrations of IL- 10 or IL4. Conditioned media were collected and subjected to ELISA for determination of $92-\mathrm{kD}$ gelatinase $(A)$ and TIMP $(B)$ content. Values represent mean $\pm \operatorname{SEM}(\mathrm{n}=3)$ of 1 experiment which is representative of three experiments with similar results. upon TIMP-1 mRNA expression was observed, without effect on $92-\mathrm{kD}$ gelatinase mRNA levels. Since the effect of IL-10 upon $92-\mathrm{kD}$ gelatinase and TIMP-1 mRNA parallel those observed by protein determinations (Figs. 1 and 2), we conclude that IL-10 modulates metalloproteinase and TIMP-1 expression in a pretranslational manner.

Relative effectiveness of various cytokines in modifying the production of 92-kD gelatinase and TIMP-1 by alveolar macrophages. We next compared the relative efficacy of different soluble mediators released by activated T-lymphocytes, including IL-2, IL-4, IL-6, IL-10, and IFN $\gamma$, to regulate the expression of $92-\mathrm{kD}$ gelatinase and TIMP-1 by macrophages. Interstitial collagenase was not measured because it is not secreted basally nor can it be induced by any of these cytokines. As shown in Fig. 6, 92-kD gelatinase and TIMP-1 were produced by macrophages under basal conditions in culture. The addition of IL-4

Table I. Effect of IL-10 on 92-kD Gelatinase and TIMP-1 Production by Human Alveolar Macrophages and Human Peripheral Blood Monocytes

\begin{tabular}{|c|c|c|}
\hline Experimental conditions & $92 \mathrm{kD}$ & TIMP-1 \\
\hline $48 h$ & \multicolumn{2}{|c|}{$n g / m l$} \\
\hline \multicolumn{3}{|l|}{ Human Alveolar Macrophages } \\
\hline Control & 257 & $<10$ \\
\hline IL-10 (10 ng/ml) & 131 & 143 \\
\hline$\alpha \mathrm{IL}-10(20 \mu \mathrm{g} / \mathrm{ml})$ & 240 & $<10$ \\
\hline $\mathrm{IL}-10+\alpha \mathrm{IL}-10$ & 238 & $<10$ \\
\hline mIgG $(1 / 50)$ & 289 & $<10$ \\
\hline IL-10 + mIgG & 169 & 181 \\
\hline \multicolumn{3}{|c|}{ Human Peripheral Blood Monocytes } \\
\hline Control & 1118 & 1040 \\
\hline IL-10 $(10 \mathrm{ng} / \mathrm{ml})$ & 273 & 1707 \\
\hline$\alpha \mathrm{IL}-10(20 \mu \mathrm{g} / \mathrm{ml})$ & 1483 & 907 \\
\hline $\mathrm{IL}-10+\alpha \mathrm{IL}-10$ & 543 & 897 \\
\hline mIgG (1/50) & 950 & 933 \\
\hline IL-10 + mIgG & 238 & 1547 \\
\hline
\end{tabular}

Macrophages and peripheral blood monocytes were cultured in the presence of IL-10 $(10 \mathrm{ng} / \mathrm{ml}) \pm$ antibody to IL-10 $(\alpha \mathrm{IL}-10$ to $20 \mu \mathrm{g} / \mathrm{ml})$ or \pm a nonspecific antibody (mIgG) for $48 \mathrm{~h}$. Conditioned media were harvested and tested for 92-kD gelatinase and TIMP-1 levels.
( $10 \mathrm{ng} / \mathrm{ml}), \mathrm{IL}-10(10 \mathrm{ng} / \mathrm{ml})$, and IFN $\gamma(500 \mathrm{U} / \mathrm{ml})$ decreased $92-\mathrm{kD}$ enzyme production by 60,30 , and $76 \%$, respectively (Fig. $6 \mathrm{~A}$ ). Although synthesis of $92-\mathrm{kD}$ gelatinase was reduced on average by $35 \%$ with $10 \mathrm{ng} / \mathrm{ml}$ of IL-10, both higher and lower degrees of inhibition were observed among the different individuals' alveolar macrophages (Figs. 1 and 4, Tables I and II). Furthermore, cell supernatants subjected to gelatin zymography and subsequently scanned densitometrically showed a decrease of at least $30 \%$ in $92-\mathrm{kD}$ gelatinolytic activity (data not shown). IL-6 and IL-2 failed to affect production of 92-kD gelatinase by macrophages.

Of the cytokines tested, only IL-10 $(10 \mathrm{ng} / \mathrm{ml})$ and IL-6 $(10 \mathrm{ng} / \mathrm{ml})$ stimulated the production of TIMP-1 by alveolar macrophages (Fig. 6). Both cytokines increased TIMP-1 expression by nearly 5 -fold above baseline levels. Thus, IL-10 was the only cytokine to simultaneously reduce MMP and enhance TIMP-1 production.

Capacity of IL-10 to influence the production of interstitial collagenase and TIMP-1 by human dermal and lung fibroblasts. To assess the cell type-specificity of the effect of IL-10, we studied human dermal and lung fibroblasts treated with the cytokine. Cells were cultured under control conditions and also in the presence of added IL-10 and/or IL- $1 \beta$. In the case of skin fibroblasts, IL-10 failed to inhibit the basal production of interstitial collagenase and reduced IL-1-stimulated enzyme

Table II. IL-10 Inhibits Metalloproteinase and Stimulates TIMP-1 Production by Human Alveolar Macrophages Exposed to Killed S. aureus

\begin{tabular}{lccc}
\hline \multicolumn{1}{c}{ Experimental conditions } & C'ase & $92 \mathrm{kD}$ & TIMP-1 \\
\hline \multicolumn{1}{c}{$48 \mathrm{~h}$} & & $n g / m l$ & \\
Control & $<10$ & $158 \pm 31$ & $<10$ \\
$\mathrm{IL}-10(10 \mathrm{ng} / \mathrm{ml})$ & $<10$ & $88 \pm 5$ & $220 \pm 26$ \\
k.Staph. $(10 \mathrm{org} / \mathrm{M} \varnothing)$ & $208 \pm 22$ & $359 \pm 20$ & $101 \pm 28$ \\
k.Staph. + IL-10 $(10 \mathrm{ng} / \mathrm{ml})$ & $<10$ & $162 \pm 33$ & $388 \pm 39$ \\
& & & \\
\hline
\end{tabular}

Macrophages were cultured at $1 \times 10^{6} \mathrm{cells} / \mathrm{ml}$ in the presence of killed S. aureus $(10$ organisms $/ \mathrm{M} \varnothing)$ with or without IL-10 $(10 \mathrm{ng} / \mathrm{ml})$. After $48 \mathrm{~h}$ of incubation, the conditioned media were analyzed for interstitial collagenase, $92-\mathrm{kD}$ gelatinase and TIMP levels. Mean \pm SEM from one experiment which is representative of three experiments. 


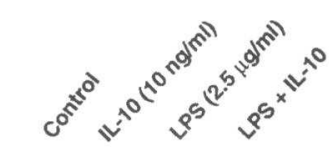

Interstitial Collagenase

TIMP-1

TIMP-2

Figure 4. Effect of IL-10 on the biosynthesis of macrophage interstitial collagenase, TIMP-1 and TIMP-2. Macrophages cultured in medium alone or in the presence of LPS $(2.5 \mu \mathrm{g} / \mathrm{ml})$ were exposed to IL-10 $(10 \mathrm{ng} / \mathrm{ml})$ for $48 \mathrm{~h}$. Cells were metabolically labeled with $\left[{ }^{35} \mathrm{~S}\right]-$ methionine as described under Methods. Labeled proteins were immunoprecipitated with antiserum to interstitial collagenase, TIMP-1 or TIMP2 as indicated.

production only marginally (by $<20 \%$ ) (Table III). Furthermore, the production of TIMP-1 was unaffected by IL-10. In contrast, IL- $1 \beta$ strongly increased interstitial collagenase production and slightly upregulated the production of TIMP-1. For the lung fibroblasts, IL-10 also failed to modify the expression of either interstitial collagenase or TIMP-1.

\section{Discussion}

T lymphocytes and macrophages, attracted to damaged sites by various chemotactic factors are often in close spatial proximity

Table III. Effect of IL-10 and IL-1 $\beta$ on Interstitial Collagenase and TIMP-1 Production by Dermal and Lung Fibroblasts

\begin{tabular}{lcc}
\hline \multicolumn{1}{c}{ Experimental conditions } & Collagenase & TIMP-1 \\
\hline \multicolumn{1}{c}{ 72 $h$} & percent of control & percent of control \\
Dermal Fibroblasts & & \\
Medium alone & 100 & 100 \\
IL-10 (10 ng/ml) & $109 \pm 20$ & $106 \pm 6$ \\
IL-1 $\beta(125 \mathrm{pg} / \mathrm{ml})$ & $631 \pm 126$ & $148 \pm 26$ \\
IL-10 + IL-1 $\beta(125 \mathrm{pg} / \mathrm{ml})$ & $526 \pm 105$ & $142 \pm 19$ \\
Lung Fibroblasts & & \\
Medium alone & 100 & 100 \\
IL-10 (10 ng/ml) & $116 \pm 28$ & $120 \pm 13$ \\
IL-1 $\beta(125 \mathrm{pg} / \mathrm{ml})$ & $135 \pm 13$ & $145 \pm 25$ \\
IL-10 + IL-1 $\beta(125 \mathrm{pg} / \mathrm{ml})$ & $160 \pm 5$ & $136 \pm 29$ \\
& &
\end{tabular}

Lung and dermal fibroblasts $\left(2 \times 10^{4}\right.$ cells/well $)$ were cultured in the presence of various cytokines at the indicated concentrations for $72 \mathrm{~h}$. Supernatants were harvested and analyzed by ELISAs for their content of interstitial collagenase and TIMP-1. Mean \pm SEM from five separate experiments. Amounts of spontaneously secreted collagenase and TIMP1 in dermal fibroblasts were 500 and $1066 \mathrm{ng} / \mathrm{ml}$, respectively, and in lung fibroblasts were 1234 and $1373 \mathrm{ng} / \mathrm{ml}$, respectively.

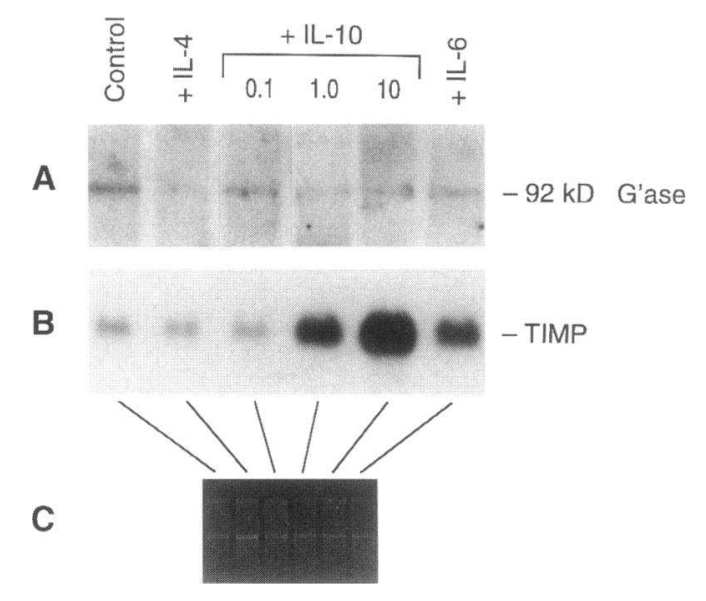

Figure 5. 92-kD gelatinase and TIMP-1 regulation by IL-10 is mediated at a pretranslational level. Human alveolar macrophages from on a single donor were cultured for $24 \mathrm{~h}$ alone or in the presence of IL-4 (10 ng/ $\mathrm{ml})$, increasing concentrations of IL-10 $(0.1,1.0$ and $10 \mathrm{ng} / \mathrm{ml})$, or IL$6(10 \mathrm{ng} / \mathrm{ml})$. Each condition utilized $10^{7}$ cells, but each lane contains $10 \mathrm{ng}$ of total RNA. Total RNA was harvested (see Methods) and subjected to Northern blot analysis using cDNA probes for $92-\mathrm{kD}$ gelatinase (A) and TIMP-1 $(B)$. The inset demonstrates the quality and content of ribosomal RNA as shown by ethidium bromide staining $(C)$.

and may interact with each other or with resident tissue cells $(12,30)$. Activated $T$ lymphocytes release several inflammatory mediators which in turn activate macrophage functions (31). Based upon their secretion of lymphokines, activated murine $\mathrm{T}$ lymphocytes can be divided into two subsets: $\mathrm{Th}_{1}$ cells which secrete predominantly IL- $2, \mathrm{IFN} \gamma$, and $\mathrm{TNF} \beta$, and $\mathrm{Th}_{2}$ cells which release predominantly IL-4, IL-5, IL-6, and IL-10 (13). However, in the human system, both $\mathrm{Th}_{1}$ and $\mathrm{Th}_{2}$ cells are capable of producing IL-10 (32).

IL-10 is a potent antiinflammatory factor with prominent effects upon monocyte-macrophages. IL-10 inhibits cytokine production by LPS-activated monocytes (15); it also inhibits the antigen-specific proliferative $\mathrm{T}$ cell response by reducing the antigen presenting capacity of monocytes via down-regulation of class II MHC antigen (18). Furthermore, IL-10 decreases the production of reactive oxygen intermediates $\left(\mathrm{H}_{2} \mathrm{O}_{2}\right)$ and reactive nitrogen intermediates (NO) by macrophages (33). In our study, we have analyzed the effects of IL-10 upon the monocyte-macrophage's capacity to modulate extracellular matrix turnover. We have shown IL-10 to be unique among lymphokines in that it simultaneously decreases the production of interstitial collagenase and $92-\mathrm{kD}$ gelatinase while enhancing TIMP-1 expression. All these combined activities on mononuclear cells would be expected to lead to powerful antiinflammatory effects. The intracellular second messenger molecules induced by IL-10 in mononuclear phagocytes have not been studied yet.

TIMP-1 is responsible for controlling the enzymatic activity of interstitial collagenase, stromelysin and $92-\mathrm{kD}$ gelatinase. Its expression in fibroblasts is stimulated by a variety of agents such as IL-1 $\beta$ (34), TGF $\beta$ (35), phorbol esters (34), and retinoids $(36)$. IL- 6 has recently been shown to specifically stimulate TIMP-1 production in fibroblasts (37) and alveolar macrophages (20), with inconsistent effect upon metalloproteinase release. We have found IL-10 to be as effective as IL- 


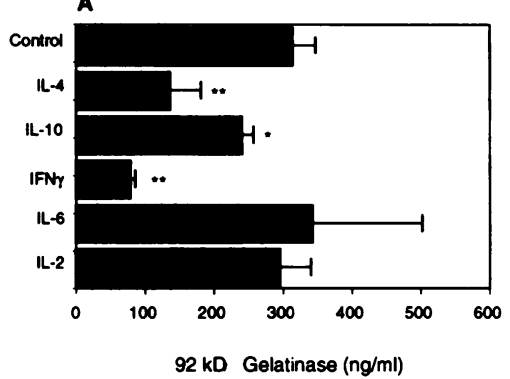

B

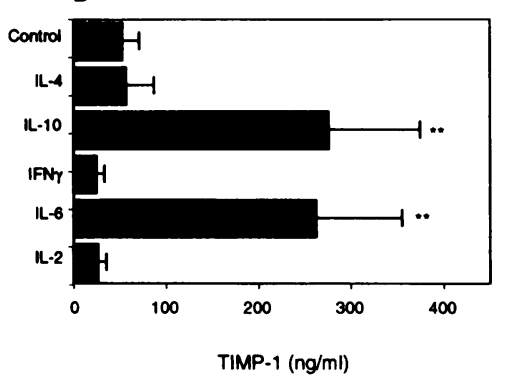

Figure 6. Comparative efficacy of various cytokines to regulate the production of $92-\mathrm{kD}$ gelatinase and TIMP1 by human alveolar macrophages. Macrophages were cultured in the presence of IL-4 $(10 \mathrm{ng} / \mathrm{ml})$, IL-10 (10 $\mathrm{ng} / \mathrm{ml}), \mathrm{IFN} \gamma(500 \mathrm{U} / \mathrm{ml})$, IL-6 $(10 \mathrm{ng} / \mathrm{ml})$, and IL$2(2 \mathrm{ng} / \mathrm{ml})$. After $48 \mathrm{~h}$ of culture, conditioned media were analyzed for content of $92-\mathrm{kD}$ gelatinase $(A)$ and TIMP-1 $(B)$. Values are means \pm SEM from 4 separate experiments, each performed in triplicate. ${ }^{* *} P<0.01$, $* P<0.05$, compared with control by paired $t$ test.
6 in inducing TIMP-1 production by alveolar macrophages, both basal levels and in cells activated with LPS or killed Staph. TIMP-2 is primarily responsible for controlling the activity of $72-\mathrm{kD}$ gelatinase (38). This inhibitor is produced constitutively at high levels by human fibroblasts (8) and alveolar macrophages (7). In macrophages, basal secretion of TIMP-2 is markedly reduced by LPS, denatured type I collagen and zymosan, factors which stimulate TIMP-1 production by the same cells (7). In contrast to its effects upon the production of TIMP-1, IL-10 failed to alter the biosynthesis of TIMP-2. Thus, IL-10 provides yet another example for the dissociated regulation of TIMP-1 and TIMP-2 in tissue macrophages.

We also compared other cytokines released by activated $\mathrm{T}$ lymphocytes to IL-10 for their capacity to modulate the matrix metalloproteinase and TIMP-1 expression of macrophages. IL4 suppressed the production of interstitial collagenase and 92$\mathrm{kD}$ gelatinase, but, in contrast to IL-10, it had no effect on TIMP-1 release $(19,20)$. IFN $\gamma$ is an established inducer of several macrophage functions, but, paradoxically, as we have previously reported, IFN $\gamma$ potently inhibited the biosynthesis of macrophage metalloproteinases (26). Thus, four major products secreted by activated T lymphocytes, IL-10, IL-4, IL-6, and IFN $\gamma$, inhibit the production of metalloproteinases by human mononuclear phagocytes and/or stimulate TIMP biosynthesis. These lymphokines may act collectively to restrict matrix destruction during inflammation.

Another interesting finding in this study is the cell typespecific nature of IL-10 regulation. When human dermal and lung fibroblasts, control or stimulated by IL- $1 \beta$, were exposed to IL-10, neither basal nor induced levels of interstitial collagenase or TIMP-1 were affected. Those results are in contradiction with results of Reitamo et al. who observed that IL-10 is able to stimulate the mRNA expression of both interstitial collagenase and stromelysin (39). Examples of such cell type-specific control are becoming more commonplace in metalloproteinase biology. For example, TGF $\beta$ has been shown to inhibit the production of metalloproteinases and augment the biosynthesis of TIMP-1 in fibroblasts (35). Yet, this cytokine stimulates 92-kD gelatinase production in both keratinocytes (40) and monocytes (41).

We have recently found that activated $\mathrm{T}$ cells can stimulate the metalloproteinase production of human mononuclear phagocytes by a mechanism which involves the expression of one or more cell surface glycoproteins induced via direct cell-cell contact (42). It is thus tempting to speculate that such activated $\mathrm{T}$ lymphocytes may utilize the secretion of cytokines versus cell-cell contact as strategies to respectively downregulate and upregulate the capacity of nearby mononuclear phagocytes to degrade the extracellular matrix. In any event, IL-10 appears to be unique among $\mathrm{T}$ cell lymphokines in suppressing the production of metalloproteinases while simultaneously inducing TIMP-1 biosynthesis. As such, IL-10 may represent an important matrix-protective cytokine during inflammation, but in vivo studies will be necessary to evaluate the effectiveness of this cytokine.

\section{Acknowledgments}

We thank F. El Habre, M.-T. Kaufmann, and R. McDonald for excellent technical assistance. We thank Dr. J. E. de Vries and Dr. J. Banchereau for providing IL-10 and $\alpha \mathrm{IL}-10$ and Y. DeClerck (University of California, Los Angeles) for supplying TIMP-2 antiserum. We also thank Dr. A. Spiliopoulos and staff of the University Hospital of Geneva for collecting and supplying lung tissue.

This work was supported by grant no 31-33786-92 (J.-M. Dayer) from the Swiss National Science Foundation, by grant HL-29594 from United States Public Health Service and grant 3524 from the Council for Tobacco Research (H. G. Welgus). S. Lacraz is the recipient of an $\mathrm{MD} / \mathrm{PhD}$ fellowship at the Medical Faculty of Geneva University, donated by the Swiss Academy of Medical Sciences.

\section{References}

1. Senior, R. M., E. J. Campbell, J. A. Landis, F. R. Cox, C. Kuhn, and H. S Koren. 1982. Elastase of U-937 monocytelike cells: comparisons with elastases derived from human monocytes and neutrophils and murine macrophagelike cells. J. Clin. Invest. 69:384-393.

2. Welgus, H. G., E. J. Campbell, Z. Bar-Shavit, R. M. Senior, and S. L. Teitelbaum. 1985. Human alveolar macrophages produce a fibroblast-like collagenase and collagenase inhibitor. J. Clin. Invest. 76:219-224.

3. Collier, I. E., G. A. P. Bruns, G. I. Goldberg, and D. S. Gerhard. 1991. On the structure and chromosome location of the 72- and 92-kDa human type IV collagenase genes. Genomics. 9:429-434.

4. Wilhelm, S. M., I. E. Collier, B. L. Marmer, A. Z. Eisen, G. A. Grant, and G. I. Goldberg. 1989. SV-40-transformed human lung fibroblasts secrete a 92 $\mathrm{kDa}$ type IV collagenase which is identical to that secreted by normal lung macrophages. J. Biol. Chem. 264:17213-17221.

5. Shapiro, S. D., D. K. Kobayashi, and T. J. Ley. 1993. Cloning and characterization of a unique elastolytic metalloproteinase produced by human alveolar macrophages. J. Biol. Chem. 268:23824-23829.

6. Albin, R. J., R. M. Senior, H. G. Welgus, N. L. Connolly, and E. J. Campbell. 1987. Human alveolar macrophages release an inhibitor of metalloproteinase elastase in vitro. Am. Rev. Respir. Dis. 135:1281-1285.

7. Shapiro, S. D., D. K. Kobayashi, and H. G. Welgus. 1992. Identification of TIMP-2 in human alveolar macrophages: regulation of biosynthesis is opposite to that of metalloproteinases and TIMP-1. J. Biol. Chem. 267:13890-13894.

8. Howard, E. W., E. C. Bullen, and M. J. Banda. 1991. Regulation of the autoactivation of human 72-kDa progelatinase by tissue inhibitor of metalloproteinases-2. J. Biol. Chem. 266:13064-13069.

9. McCachren, S. S. 1991. Expression of metalloproteinases and metalloproteinase inhibitor in human arthritic synovium. Arthritis Rheum. 34:1085-1093.

10. Henney, A. M., P. R. Wakeley, M. J. Davies, K. Foster, R. Hembry, G. Murphy, and S. Humphries. 1991. Localization of stromelysin gene expression 
in atherosclerotic plaques by in situ hybridization. Proc. Natl. Acad. Sci. USA. 88:8154-8158

11. Stout, R. D. 1993. Macrophage activation by T cells: cognate and noncognate signals. Curr. Opin. Immunol. 5:398-403.

12. Vey, E., J.-H. Zhang, and J.-M. Dayer. 1992. IFN- $\gamma$ and $1,25(\mathrm{OH})_{2} \mathrm{D}_{3}$ induce on THP-1 cells distinct patterns of cell surface antigen expression, cytokine production, and responsiveness to contact with activated T cells. J. Immunol. 149:2040-2046.

13. Mosmann, T. R., and R. L. Coffman. 1989. $\mathrm{Th}_{1}$ and $\mathrm{Th}_{2}$ cells: different patterns of lymphokine secretion lead to different functional properties. Ann. Rev. Immunol. 7:145-173.

14. Fiorentino, D. F., M. W. Bond, and T. R. Mosmann. 1989. Two types of mouse helper $\mathrm{T}$ cell. IV. $\mathrm{Th}_{2}$ clones secrete a factor that inhibits cytokine production by $\mathrm{Th}_{1}$ clones. J. Exp. Med. 170:2081-2095.

15. de Waal Malefyt, R., J. Abrams, B. Bennett, C. G. Figdor, and J. E. de Vries. 1991. Interleukin-10 (IL-10) inhibits cytokine synthesis by human monocytes - an autoregulatory role of IL-10 produced by monocytes. J. Exp. Med. 174:1209-1220.

16. Vieira, P., R. de Waal Malefyt, M.-N. Dang, K. E. Johnson, R. Kastelein, D. F. Fiorentino, J. E. de Vries, M.-G. Roncarolo, T. R. Mosmann, and K. W. Moore. 1991. Isolation and expression of human cytokine synthesis inhibitory factor cDNA clones: homology to Epstein-Barr virus open reading frame BCRF I. Proc. Natl. Acad. Sci. USA. 88:1172-1176.

17. Rivas, J. M., and S. E. Ullrich. 1992. Keratinocyte-derived IL-10. J. Invest. Dermatol. 98:578-583.

18. de Waal Malefyt, R., J. Haanen, H. Spits, M. G. Roncarolo, A. A. te Velde, C. Figdor, K. Johnson, R. Kastelein, H. Yssel, and J. E. de Vries. 1991. IL-10 and v-IL-10 strongly reduce antigen-specific human $\mathrm{T}$ cell proliferation by diminishing the antigen-presenting capacity of monocytes via downregulation of class II MHC expression. J. Exp. Med. 174:915-924.

19. Corcoran, M. L., W. G. Stetler-Stevenson, P. D. Brown, and L. M. Wahl. 1992. Interleukin-4 inhibition of prostaglandin $E_{2}$ synthesis blocks interstitial collagenase and $92-\mathrm{kDa}$ type IV collagenase/gelatinase production by human monocytes. J. Biol. Chem. 267:515-519.

20. Lacraz, S., L. P. Nicod, B. Galve-de Rochemonteix, C. Baumberger, J.-M. Dayer, and H. G. Welgus. 1992. Suppression of metalloproteinase biosynthesis in human alveolar macrophages by IL-4. J. Clin. Invest. 90:382-388.

21. Galve-de Rochemonteix, B., L. P. Nicod, A. F. Junod, and J.-M. Dayer. 1990. Characterization of a specific 20 - to $25-\mathrm{kD}$ interleukin-1 inhibitor from cultured human lung macrophages. Am. J. Respir. Cell Mol. Biol. 3:355-361.

22. Dayer J.-M., B. de Rochemonteix, B. Burrus, S. Demczuk, and C. A. Dinarello. 1986. Human recombinant interleukin-1 stimulates collagenase and prostaglandin $\mathrm{E}_{2}$ production by human synovial cells. J. Clin. Invest. 77:645648.

23. Cooper, T. W., E. A. Bauer, and A. Z. Eisen. 1982. Enzyme-linked immunosorbent assay for human skin collagenase. Collagen Rel. Res. 3:205-216.

24. Bergmann, U., J. Michaelis, R. Oberhoff, V. Knäuper, R. Beckmann, and H. Tschesche. 1989. Enzyme-linked immunosorbent assays for the quantitative determination of human leukocyte collagenase and gelatinase. J. Clin. Chem. Clin. Biochem. 27:351-359.

25. Welgus H. G., and G. P. Stricklin. 1983. Human skin fibroblast collagenase inhibitor: comparative studies in human connective tissues, serum, and amniotic fluid. J. Biol. Chem. 258:12259-12264.
26. Shapiro, S. D., E. J. Campbell, D. K. Kobayashi, and H. G. Welgus. 1990 Immune modulation of metalloproteinase production in human macrophages. Selective pretranslational suppression of interstitial collagenase and stromelysin biosynthesis by interferon- $\gamma$. J. Clin. Invest. 86:1204-1210.

27. King, J., and U. K. Laemmli. 1971. Polypeptides of the tail fibres of bacteriophage T4. J. Mol. Biol. 62:465-477.

28. Chirgwin, J. M., A. E. Przybyla, R. J. MacDonald, and W. J. Rutter. 1979. Isolation of biologically active ribonucleic acid from sources enriched in ribonuclease. Biochemistry. 18:5294-5299.

29. Stähle-Bäckdahl, M., B. D. Sudbeck, A. Z. Eisen, H. G. Welgus, and W. C. Parks. 1992. Expression of 92-kDa type IV collagenase mRNA by eosinophils associated with basal cell carcinoma. J. Invest. Dermatol. 99:497-503.

30. Krzesicki, R. F., W. E. Fleming, G. E. Winterrowd, C. A. Hatfield, M. E. Sanders, and J. E. Chin. 1991. T lymphocyte adhesion to human synovial fibroblasts. Role of cytokines and the interaction between intercellular adhesion molecule 1 and CD11a/CD18. Arthritis Rheum. 34:1245-1253.

31. Paulnock, D. M. 1992. Macrophage activation by T cells. Curr. Opin Immunol. 4:344-349.

32. Del Prete G., M. De Carli, F. Almerigogna, M. G. Giudizi, R. Biagiotti, and S. Romagnani. 1993. Human IL-10 is produced by both type 1 helper $\left(\mathrm{Th}_{1}\right)$ and type 2 helper $\left(\mathrm{Th}_{2}\right) \mathrm{T}$ cell clones and inhibits their antigen-specific proliferation and cytokine production. J. Immunol. 150:353-360.

33. Cunha, F. Q., S. Moncada, and F. Y. Liew. 1992. Interleukin 10 (IL10) inhibits the induction of nitric oxide synthetase by interferon- $\gamma$ in murine macrophages. Biochem. Biophys. Res. Commun. 1992:1155-1159.

34. Murphy, G., J. J. Reynolds, and Z. Werb. 1985. Biosynthesis of tissue inhibitor of metalloproteinases by human fibroblasts in culture. Stimulation by 12-o-Tetradecanoylphorbol 13-acetate and interleukin 1 in parallel with collagenase. J. Biol. Chem. 260:3079-3083.

35. Overall, C. M., J. L. Wrana, and J. Sodek. 1991. Transcriptional and posttranscriptional regulation of $72-\mathrm{kDa}$ gelatinase/type IV collagenase by transforming growth factor- $\beta 1$ in human fibroblasts. J. Biol. Chem. 266:14064-14071.

36. Clark S. D., D. K. Kobayashi, and H. G. Welgus. 1987. Regulation of the expression of tissue inhibitor of metalloproteinases and collagenase by retinoids and glucocorticoids in human fibroblasts. J. Clin. Invest. 80:1280-1288.

37. Lotz, M., and P.-A. Guerne. 1991. Interleukin-6 induces the synthesis of tissue inhibitor of metalloproteinases-1/erythroid potentiating activity (TIMP-1/ EPA). J. Biol. Chem. 266:2017-2020.

38. Stetler-Stevenson, W. G., H. C. Krutzsch, and L. A. Liotta. 1989. Tissue inhibitor of metalloproteinase (TIMP-2). A new member of the metalloproteinase inhibitor family. J. Biol. Chem. 264:17374-17378.

39. Reitamo, S., A. Remitz, K. Tamai, and J. Uitto. 1994. Interleukin-10 modulates type I collagen and matrix metalloprotease gene expression in cultured human skin fibroblasts. J. Clin. Invest. 94:2489-2492.

40. Salo, T., J. G. Lyons, F. Rahemtulla, H. Birkedal-Hansen, and H. Larjava 1991. Transforming growth factor- $\beta 1$ up-regulates type IV collagenase expression in cultured human keratinocytes. J. Biol. Chem. 266:11436-11441.

41. Wahl, S. M., J. B. Allen, B. S. Weeks, H. L. Wong, and P. E. Klotman 1993. Transforming growth factor $\beta$ enhances integrin expression and type IV collagenase secretion in human monocytes. Proc. Natl. Acad. Sci. USA. 90:45774581 .

42. S. Lacraz, P. Isler, E. Vey, H. G. Welgus, and J.-M. Dayer. 1994. Direct contact between $\mathrm{T}$ lymphocytes and monocytes is a major pathway for the induction of metalloproteinase expression. J. Biol. Chem. 269:22027-22033. 